\author{
С.М. Толстая \\ Институт славяноведения РАН \\ (Россия, Москва) \\ smtolstaya@yandex.ru
}

\title{
МЕХАНИЗМЫ ЛЕКСИЧЕСКОЙ МНОГОЗНАЧНОСТИ: ЗАМЕТКИ НА ПОЛЯХ «АКТИВНОГО СЛОВАРЯ»
}

«Активный словарь русского языка» под редакцией Ю.Д. Апресяна по-новому ставит проблему лексической многозначности, ее системности, типологии и механизмов, лежащих в ее основе. Разные классы слов в разной степени обладают свойством многозначности и характеризуются разными типами многозначности. В целом для предметной лексики свойство многозначности характерно в меньшей степени, чем для предикатной лексики и особенно глаголов. Это объясняется сложностью актантной структуры глагола и зависимостью семантики глагола от классов его актантов. В основе лексической многозначности лежат следующие системные механизмы: метонимия и метафора (характерны как для предметной, так и для предикатной лексики), фундаментальная классификация предикатов и предикатных имен, система их семантических (функциональных) актантов (субъект, объект, контрагент, пациенс, инструмент, средство, цель, локус, время, способ и др.) и «таксономическая» классификации лексики (как предметной, так и предикатной). В статье эти положения иллюстрируются толкованиями глаголов вести, валять и др. Основным различием между лексемами глагола вести является различие в лексическом классе объекта или пациенса (лицо или группа лиц, транспортное средство, занятие или деятельность, предмет - указка, палец, глаз и т. п.). Общей семантической основой для выделяемых значений (лексем) является каузация движения объекта. Формальным показателем этой общности служит то, что объекты (пациенсы) действия «вести» стандартно сочетаются с предикатом идти (человек идет, машина идет, урок идет, исследования идут и т.д.). Для глагола валить общей семантической основой лексем можно считать каузацию изменения положения объекта в пространстве. Лексема многозначного слова не всегда является семантическим дериватом какой-то другой лексемы этого слова - она может появляться «извне», т. е. возникать под влиянием других слов, находящихся в системной связи с данным словом (синонимов, антонимов, конверсивов, аналогов, дериватов и т. п.), и/или путем конденсации устойчивых выражений с данным словом. 
Ключевые слова: лексическая многозначность, лексические классы, предметная лексика, предикатная лексика, семантика, семантическая деривация.

«Активный словарь русского языка» [AC], создаваемый по замыслу и под редакцией Ю.Д. Апресяна, воплощает принципы и подходы интегральной лексикографии, требующие, чтобы для каждого слова были указаны все грамматические, синтаксические, просодические, стилистические и прочие характеристики, необходимые для его правильного употребления, и учтены все парадигматические связи лексемы - ее вхождение в синонимические ряды, антонимические оппозиции, отношения конверсии, словообразовательные отношения и т. д. Однако главные особенности словаря, отличающие его от имеющихся толковых словарей русского языка, заключены в его семантическом содержании, т. е. в принципиально новом подходе к выделению и толкованию значений слов (лексем). Если предыдущий труд авторского коллектива - «Новый объяснительный словарь синонимов» [НОСС] - предложил по существу новую концепцию синонимии и новый подход к ее лексикографическому представлению, то «Активный словарь» по-новому ставит проблему лексической многозначности, ее системности, типологии и механизмов, лежащих в ее основе.

\section{1. Лексические классы и многозначность}

Если читать «Активный словарь» подряд (а это увлекательное и поучительное чтение), то нельзя не заметить, что разные классы слов в разной степени и в разном качестве обладают свойством многозначности (характеризуются разными типами многозначности). Есть слова, вообще не обладающие этим свойством, и это, по крайней мере для некоторых типов слов, объяснимо. Таковы прежде всего «предметные» (номенклатурные) имена. По материалам первых трех томов [AC] это некоторые названия растений (василек, верба, водоросли, георгин, гроздь, земляника), животных (верблюд, воробей, ворон, вошь, грач), веществ и материалов (вата, витамин, вещество, водород, воск), частей тела (веки, вена, веснушки, вымя, затылок), артефактов (велосипед, веревка, вертолет, винтовка, виолончель, водопровод, гармонь, градусник, графин, диван, дверь), явлений природы (вьюга, зной). При этом другие представители этих классов могут быть многозначными, хотя и в ограниченной степени (например, среди названий растений регулярны совмещения значений дерева и его плода, для названий животных типичны вторичные, метафорические наименования людей, регулярно совмещаются значения контейнера и содержимого, учреждения и занимаемого им здания и т. п. [Апресян 1974: 200-203]). Но среди моносемичных слов есть и предикаты действий (ворковать, вскипятить), состояний (гнев, грипп, забытье), имена локусов (галактика, заграница, захолустье), лиц (вратарь, врач, всадник, депутат, доярка, дворяне, житель), абстрактных понятий (воображение, гул, зрение) и т. П., для которых отсутствие полисемии в большей мере индивидуально (т.е. не касается всего класса имен, не предопределено принадлежностью к определенному классу имен). 
На противоположном полюсе находится глагольная лексика, для которой полисемия характерна в высшей степени, что объясняется сложностью актантной структуры глагола и его разными позициями в фундаментальной классификации предикатов [Апресян 2009: 27-39].

Семантическая (категориальная $\left.{ }^{1}\right)$ классификация лексики и многозначность связаны двояким образом: во-первых, каждый лексический класс характеризуется своей степенью и своим характером многозначности; во-вторых, принадлежность слова к определенному классу влияет на многозначность других слов (прежде всего глаголов, но и других предикатных слов), по отношению к которым данный класс лексики выступает в роли того или иного актанта. Многозначность предметной лексики основывается главным образом на метафоре и метонимии, а предикатной - на принадлежности к фундаментальному классу предикатов и на лексическом классе актантов, среди которых наибольшее значение имеет субъект (субъект действия, занятия, состояния, свойства и др.), точнее его принадлежность к классу лиц или других предметных сущностей. При этом замена субъекта-лица субъектом другого класса тоже может основываться на метонимии и метафоре: бледный человек > бледное лицо (метонимия) > бледная статья, т. е. невыразительная, лишенная красок (метафора).

Семантическая классификация лексики в версии Московской семантической школы исходит из того, что «все лексемы и другие эквивалентные им лексические единицы, в том числе и многословные, делятся прежде всего на два типа - предметные (названия животных, птиц, рыб, овощей, фруктов, камней, гор, планет, светил и т.п.) и предикатные (в данном контексте любые валентные лексемы) <..> Двум разрядам лексики и, соответственно, двум типам толкований соответствуют и две разные семантические классификации языковых единиц - таксономическая и фундаментальная. Первая предназначена для предметных единиц (например, названий различных объектов живой и неживой природы), а вторая — для предикатных» [Апресян 2009: 27-28]. Представляется, однако, что эти две классификации не противопоставлены друг другу, а скорее накладываются друг на друга. Предметные имена, будучи объектом таксономической классификации, в то же время прямо или опосредованно участвуют в семантической организации предикатной лексики в качестве ее актантов. Физический предмет может быть объектом, инструментом, орудием действия (поднять молоток, ударить молотком, починить молоток и т. п.), природное имя вода может выступать в роли материала, локуса, действующей силы, средства и т.п. В семантике многозначного прилагательного воздушный мотивирующее слово воздух присутствует в разных категориальных значениях: материи (воздушный поток), локуса (воздушный флот), «инструмента» (воздушный насос), средства (воздушное отопление). Семантическая структура

${ }^{1}$ В отличие от «тематической», по семантическим полям. Подобно тому как в сфере предикатов выделяются фундаментальные классы (действий, занятий, состояний, свойств и т.д.), среди имен могут быть выделены функциональные классы: предметов природы, артефактов, имена лиц, инструментов, локусов, времени, действий, состояний, свойств и т. д. Каждый из них обладает своими особыми «ролевыми» характеристиками в формировании структуры многозначности. 
предикатов, в свою очередь, зависит от таксономической классификации: скажем, в пределах акционального класса предикатов выделяются предикаты физических действий, движения, ментальных действий, речи и т. д., которые имеют разный набор актантов и разную структуру многозначности.

Понятие предикатной лексики не имеет строгого определения. Прототипическим классом предикатной лексики, естественно, являются глаголы, для семантического описания которых применяется фундаментальная классификация. Этой же классификации подчинены и предикатные имена (имена действий, занятий, состояний, процессов, свойств и т. д.) [Апресян 2004]2. Не вполне понятно, однако, какое место в этой классификации должны занимать имена лиц (nomina personalis), не все из которых «предикатны».

С одной стороны, это имена, которые обозначают занятия, функции или характерные действия человека и имеют свою актантную структуру, например автор нашумевшего романа, беженец из Чечни, виновник происшествия, владелец имущеества, водитель трамвая, дежурный по столовой, диктор радио, дирижер оркестра, директор школь, жертва покушения, житель поселка, заведующий отделом, заказчик такси, заместитель директора, заложник у бандитов, зачинщик беспорядков, защитник животных и т. п. С другой стороны, это названия лиц по их национальности, званию, статусу, личным качествам, которые не имеют в своей семантике предикативного компонента: американиьь, англичане, арабы, армяне, архиепископ, атеист, африканец, барон, близнецьь, блондин, богатырь, болгары, брюнет, варвар, великан, волшебник, гигант, глухонемой, голландиьы, граф, греки, гроссмейстер, грузинь, дама, дворяне, девица, девка, девочка, девушка, декабрист, демократ, дикарь, дура, дурак, евреи, епископ, ефрейтор, женшина и т.п. И те и другие тем не менее едины в отношении многозначности - для них многозначность либо вовсе не характерна (ср. дипломат, дирижер, зять), либо крайне ограниченна (ср. барон, девочка, деятель) и сводится к переносным или ироническим употреблениям. У многих имен лиц управление ограничивается указанием на отношение родства, принадлежности или на объект действия: брат бабушки, жена друга, командир роты, директор института и т. п. Главное свойство лексики с категориальным значением лица - в том, что она может выступать при глаголе или предикатном имени в роли субъекта или объекта (контрагента), создавая в каждом из этих случаев самостоятельное значение, отличное от случаев с актантами другого (не персонального) типа (ср. вошел человек в дом - вошел корабль в гавань; защита девушки от хулиганов - защчита глаз от солнияа).

Точно так же далеко не все прилагательные и наречия подпадают под понятие предикатной лексики. Прилагательные, обозначающие свойства, лишь частично могут считаться предикатными именами, и это, как правило, отглагольные дериваты: бдительный, бегльй, бережливый, болтливый, больной, бывиий, верный,

${ }^{2}$ Ср. в другой терминологии: «Моделью управления должны снабжаться не только глаголы, но и многие разряды существительных, формально или семантически производных от глагола, ср. авторитет (кого, среди кого, в чем), соглашение (кого, с кем, о чем)» [Апресян 1974: 134]. 
влиятельный, влюбленньй, вместительныци, возмутительный, вооруженный, вопиющчй, вопросительный, воспитанный, восприимчивый, врожденный, вспомогательныцй, вспьльчивыли, вступительный, встречный, вымышленныцй, выносливый, губительный, доверчивый, жгучий, живучий, забитылй, забытый, загорельй , закрытылй, заметныц̆, замкнутыц̆, запоздальй, запутанныц̆, запущенныци, заразительныцй, заслуженнылй, застывщий, защчитнылй, зылбкий и т. п. Бо́льшая же часть прилагательных - как качественных, так и относительных (производных от предметных имен) - в своем основном значении не имеет актантной семантики: алыцй, бедныци, бельій, бурнылй, быстрый, важныцй, великий, весельій, выссокий, глубокий, глупьй, глухой, густой, голубой, голый, грубый, грудной, грустнылй, грязнылй, дикий, деревянный, детский, дешевый, дорожный, жирный, жуткий, знойный и т. п.

Не удается истолковать как предикатные и некоторые абстрактные имена ( $a c$ трономия, был, добро, зло и т. п.).

Среди предикатной именной лексики наиболее регулярным классом являются существительные - и ме на дей с т в й, зан я тий, с ост о яний, проце с сов и т.д., система многозначности которых, как правило, воспроизводит (в той или иной степени) структуру многозначности исходных глаголов (ср. выйти и выход, защищщать и защита), но получает и дальнейшую деривацию, т. е. дополнительно к акциональной семантике развивает «предметные», локативные или иные актантные значения (ср. выход, проезд, переход и т. п.).

Особую группу предикатных имен составляют семантические дериваты со значением не самого предиката, а результата или продукта соответствующего действия, т. е. такие, которые получают «предметные» значения, минуя стадию акционального имени, например выгода, вылгрыш, вымысел, выручка, выставка, гудок, дар, добыча, договор, доход, задание, задаток, залог, замысел, запас, заповедь, запрет, запрос, заработок, зародыши, зарплата, заряд, засада, заслуга, затея, затруднение, заявка, заявление, звание, звон, злоупотребление, значение, зрелище.

К предикатным именам относятся также имена с остояний (агония, азарт, аллергия, анархия, ангина, антипатия, аппетит, банкротство, бедность, бездействие, безмолвие, безразличие, безумие, беспокойство, беспорядок, бессмертие, бессонница, бесчувствие, бешенство, благодарность, благополучие, благосостояние, блаженство, богатство, болезнь, боль, боязнь, брак, бред, влечение, внимание, возмущение, воодушевление, воспаление, восторг, восхищение, гипноз, гнев, голод, гордость, горе, горячка, грипп, грубость, грусть, дрожь, жажда, жалость, жар, желание, забытье, зависимость, зависть, задор, замешательство, застой, затишье, зуд), с о бы т и й (авария, банкет, беда, бедствие, бунт, война, гибель, годовщинна, давка, затор, зачет), с в о й с т в — в субстантивном (бестактность, благо, блеск, близость, величие, веселье, волиебство, вольность, выдержка, глупость, дерзость, доброта, духота, жадность, жестокость, забота, здоровье, злость) и адъективном (см. выше) выражении.

Остается еще несколько классов имен: параметрически е (возраст, высота, выиина, глубина, градус, груз, диагональ, длина, дистанция и т. п.), а б с т ра к т ные имена (авторитет, акцент, алгоритм, алиби, анатомия, аргумент, 
археология, архитектура, астрономия, баланс, беззаконие, безопасность, безработииа, биография, биология, блат, ботаника, брак, буддизм, быт, бюджет, вакансия, вариант, вера, верность, вероятность, вещество, вид, видимость, вкус, внешность, возможность, воля, воображение, впечатление, вражда, вред, время, география, гигиена, голос, графика, действительность, демократия, диагноз, диета, диктатура, дипломатия, дисииплина, добро, доверие, долг, достоинство, достояние, дружба, дух, душа, единство, жизнь, задача, закономерность, запах, звук, здравоохранение, зло, зоология, зрение), о ц е н о чн ы е (или интерпретационные) имена (абсурд, безобразие, грех).

Таким образом, лексическая многозначность базируется на следующих системных механизмах: метонимии и метафоре (это касается как предметной, так и предикатной лексики), фундаментальной классификации предикатов и предикатных имен, системе их семантических актантов (субъект, объект, контрагент, пациенс, инструмент, средство, цель, локус, время, способ и др.) и «таксономической» классификации лексики (как предметной, так и предикатной). Эти факторы часто взаимосвязаны, например изменению таксономического класса субъекта соответствует изменение фундаментального класса предиката [см. также: Толстая 2015].

\section{2. Разбор конкретных примеров из [АC]}

Продемонстрируем роль этих факторов (механизмов многозначности) на примере глагола вести. В [АС 2: 81] для этого глагола предлагается следующий набор лексем; приводится синопсис с упрощенными толкованиями:

1. 'сопровождать кого-л.' : вести бабушку под руку;

2.1. 'возглавлять': вести мальчишек на приступ снежной крепости;

2.2. 'определять смену движений партнера в танце': вести в танго;

2.3. 'опережать соперников': Кто ведет в матче?

3. 'управлять транспортным средством': вести машину;

4.1. 'быть главным участником информационного или культурного мероприятия': вести кониерт;

4.2. 'руководить деятельностью в сфере обучения или науки': вести семинары;

4.3. 'заниматься кем-л.' : вести старшие классыл; тяжельх больных;

5.1. 'прокладывать': вести теплотрассу;

5.2. 'пролегать в каком-нибудь направлении': тропинка ведет в лес;

6. 'двигать какой-л. предмет по чему-л.' : вести указкой по экрану;

7. 'быть причиной' : переутомление ведет к ослаблению организма;

8. 'заниматься чем-л.': вести хозяйство, наблюдения;

9. 'разг. следить за кем-л.': вести скупщчика краденого.

Этот многовалентный глагол в прототипической ситуации имеет следующий набор актантов (каждый из которых может замещаться словами разных лексических классов): субъект, объект, локус, время, цель, способ и др.: Вечером мать ведет ребенка за руку из детского сада домой через парк. Они отличаются 
разной степенью обязательности. Абсолютно обязательным можно считать только субъект; второе место по степени обязательности занимает объект (пациенс). Каждый в отдельности обстоятельственный актант - со значением локуса (куда, откуда, каким путем), времени, способа и цели - может отсутствовать, но обычно хотя бы один из них в обозначении прототипической ситуации фигурирует, т. е. X ведет Y либо откуда куда, каким путем, либо зачем, с какой целью, каким образом и т. п. (при этом конечная точка и цель часто совпадают, ср. вести ребенка из иколь домой). Актанты локативного ряда и актанты способа действия, как правило, не совмещаются (т. е. или ведет за руку, или ведет через парк), поскольку первое предполагает актуально-длительное значение, а второе - узуальное. Наиболее факультативен темпоральный актант (когда, как часто и т. п.). В производных лексемах состав этих актантов сокращается, и в первую очередь за счет устранения локативных актантов, что связано с элиминацией пространственной семантики основного предиката (т.е. глагола вести). Для ситуации «вести урок» нерелевантны вопросы «откуда?» и «куда?». Если же один из актантов - предикатное слово, то глагол может «вбирать в себя» актанты, принадлежащие этому зависимому предикатному слову: ср. Он ведет агитацию среди студентов за / против нового ректора. В этом случае прототипическая актантная структура утрачивается, а глагол получает «выхолощенное» значение: вести агитацию = агитировать.

Рассмотрим кратко семантическую роль главных актантов и их лексических типов.

Наибольшее значение имеет субъект, в прототипической ситуации агенс, который может быть выражен именем лица, группы лиц или (реже) именем животного: Лошадь ведет за собой жеребенка; Собака ведет слепого; Утка ведет за собой выводок утят. В приведенном выше синопсисе тип субъекта-лица характерен для всех лексем (кроме лексем 5.2. дорога ведет в гору и 7. 'быть причиной': переохлаждение ведет к болезни); соответственно, во всех этих случаях глагол относится к фундаментальному классу действий (вести кого-л. под руку, вести машину, вести урок) или занятий (вести исследования, вести хозяйство, вести слеж$\kappa y)$. Категориальная мена субъекта (т. е. выбор на роль субъекта не «предметного», а предикатного имени) кардинально меняет семантику глагола, его фундаментальный класс и всю его актантную структуру.

В случае дорога ведет к реке (лексема 5.2) в роли субъекта выступает не лицо или вообще живое существо, а природный объект (локатив), а глагол переходит в фундаментальный класс свойств, сохраняя, однако, управление локативными актантами куда и откуда (возможно также значение маршрута: через поле к реке). Очевидно, что здесь мы имеем дело с производным значением на основе метафорического переноса: «человек> дорога» (дорога ведет человека, подобно тому как человек ведет по дороге кого-л., т. е. так же каузирует его движение).

Если субъект выражен предикатным именем (со своей актантной структурой), то глагол получает значение причины: Было признано, что разработанный им план действий ведет к успешному решению поставленной задачи. Все актанты 
локативного ряда становятся нерелевантными, хотя общая идея движения имплицитно присутствует в семантике глагола благодаря представлению о движении от плана к его реализации.

Вторым по значимости актантом является объ ект каузации, или п а и ен с (вести кого или что). В этой роли выступает прежде всего имя человека (вести ребенка в школу) или органа его тела (вести пальичем по экрану), группы людей (вести солдат в атаку), реже - животных (вести коней на водопой), затем имена артефактов (транспортных средств: вести автобус), т. е. предметные классы лексики; сюда относятся лексемы $1,2.1,3,6$. В некоторых случаях позиция ведомого объекта элиминируется, например 2.2. вести партнера (девушку) в вальсе > вести в вальсе. В лексеме 2.3. вести в счете, в игре при субъекте-человеке (игрок или команда игроков) подразумеваемым объектом служит, вероятно, счет, который нарастает (ср. вести счет) и выдвигает игрока или команду вперед по отношению к сопернику (ср. вести к победе).

Если же объектом-пациенсом служит предикатное имя, то глагол имеет значение действия (вести концерт, урок), занятия (вести наблюдение, исследования) или деятельности (вести хозяйство, борьбу) и получает разные значения в зависимости именно от фундаментального класса предикатного имени (соответственно лексемы 4.1, 4.2, 8). В этих случаях глагол вести в сочетании с именами действий, занятий и деятельности выступает в той же роли, что и глаголы оказывать, производить, совершать в сочетании с акциональными именами [см.: Апресян 2004]: вести наблюдения = наблюдать, вести слежку = следить, вести прием = принимать, вести исследования = исследовать, вести беседу = беседовать, вести учет = учитывать, вести борьбу = бороться, вести войну = воевать и т. д. Другим обобщающим эти актанты семантическим компонентом оказывается смысл «занятие» и глагол заниматься, применимый к объектам большинства лексем глагола вести: заниматься наблюдением, разысканием, исследованием, заниматься слежкой, заниматься хозяйством, но вряд ли *заниматься войной или *заниматься беседой. Из прототипических пространственных актантов здесь возможны только чисто локативные, но не направительные: вести концерт, исследование, борьбу где-л., но не откуда-л. и куда-л.; для занятий возможны и темпоральные обстоятельства: когда, с каких пор, до какого времени, как часто, постоянно, с перерывами, каждый год и т. д.

В лексемах 4.3. вести старшие классы, тяжельх больных представлен результат конденсации словосочетания и явно метонимический перенос значения актанта: вести преподавание в старших классах > вести стариие классы; вести (проводить) лечение больных, наблюдение за больными > вести больных .

Интересно сравнить структуру многозначности глагола вести с семантическим спектром его аспектуального коррелята - многократного глагола водить. Оказывается, что лексемы «прямого» характера, т. е. имеющие акциональную семантику и субъекта-агенса, у них совпадают (вести под руку - водить под руку, вести в школу - водить в школу, вести машину — водить машину, вести в атаку — водить в атаку и т.д.). Однако невозможно *водить урок, *водить исследования, 
* водить хозяйство и т. п., а водить в игре и вести в игре семантически не соотносительны, т. е. специфичны для каждого.

Лексемы многозначного слова могут разграничиваться также на основе пространственных (локативных), темпоральных, целевых, причинных, оценочных и иных «обстоятельственных» актантов (параметров ситуации), при этом каждый из них может далее подразделяться на более детальные составляющие: пространственные (где, куда, откуда, через что, во что, из чего и т. п.), темпоральные (когда, с каких пор, до каких пор, как долго и т. д.), целевые и причинные (зачем, для чего, из-за чего, от чего и т. д.), модусные (по способу действия) и др. В семантическом спектре глагола зайти хорошо видны роли этих актантов. Так, в первом блоке выделяются лексемы: 1.1. зайти куда-л. на минутку, 1.2. зайти в кабинет, 1.3. зайти на сайm, 1.4. зайти в гавань; далее выделяются направительные значения (куда и за что: вглубь леса и за угол, за черту); в общем ряду акциональных значений (зайти за дом) даются и неакциональные лексемы (изображение заходит за края рамки), а также лексемы с другим (начинательным) значением префикса (зашел разговор). В глаголе валиться лексемы различаются в зависимости от источника (импульса) этого действия: от внешней силы, от внутренней слабости, от болезни, усталости и т. д. У глагола вербовать лексемы противопоставлены по признаку цели действия: 1.1. наемников, 1.2. агентов, 2. сторонников.

\section{3. Вопрос об общей семантической основе всех значений многозначного слова}

Вопрос об общей семантической основе всех значений многозначного слова (или семантического инварианта, концептуальной схемы слова, семантического потенциала и т. п.) неоднократно обсуждался в литературе. В концепции Московской семантической школы он решается следующим образом: «Наличие семантических связей между лексемами многозначного слова не предполагает с необходимостью, что у всех его лексем обнаруживается семантический инвариант. Необходимость инварианта (не только в лексике, но и в грамматике) ни из чего не следует. В частности, известное явление цепочечной полисемии, впервые описанное еще А. Дармстетером, покоится на попарных семантических связях между соседними лексемами, а первое и последнее или одно из последних звеньев этой цепочки могут не иметь друг с другом ничего общего; ср. Шел по улице отряд Ей идет новая иляпка» [Апресян 2009: 425-426].

Однако для отдельных блоков значений большинства многозначных слов некий семантический инвариант (разной степени абстрактности) может быть установлен. Как раз в случае с глаголом вести общая семантическая основа просматривается для большинства выделенных значений (лексем). Эта общая основа может быть

3 Заметим, однако, что даже и в этом последнем случае (Ей идет новая иляпка), где, казалось бы, предикат полностью оторвался от прототипического акционального значения глагола $и д т и$, его связь с этим прототипическим значением «поддерживается» такими выражениями, как подходить кому / чему-л., похожий и особенно подходить к (лицу, костюму, обстановке и т. п.). 
определена как каузация движения объекта (т. е. делать так, чтобы объект двигался, шел куда-л. или каким-л. образом). Реальность этой семантической общности подтверждается тем, что объекты (пациенсы) действия «вести» в норме сочетаются с предикатом идти (или двигаться, развиваться, т. е. совершать поступательное движение). Иначе говоря, тот или то, кого / что ведут, сам при этом идет: вести бабушку - бабушка идет, вести мальчишек на приступ крепости - мальчишки идут на приступ крепости; машина идет, концерт идет, семинар идет, теплотрасса идет, работа идет, борьба идет, исследование идет, дорога идет и т. д.

Для некоторых из выделенных лексем семантика каузации движения неочевидна, и это может объясняться какими-то специальными причинами, прежде всего особыми акцентами в восприятии соответствующей ситуации или внутриязыковыми причинами. Например, вести в танщуе подразумевает или пациенса, которого ведут (партнера), или ведение, ход самого танца как занятия (ср. вести разговор). То же, вероятно, можно сказать о лексеме 9. в специальном детективном значении: вести кого-л. в этом случае метонимически производно от выражения вести слежку за кем-л.

В случае лексемы 5.2. 'пролегать в каком-л. направлении' (Дорога ведет к храмy) мы имеем дело с характерным явлением антропоцентричности, когда семантика глагола подразумевает в качестве объекта (пациенса) человека, совершающего движение, т. е. вести в этом употреблении означает что-то вроде 'дорога ведет человека к храму'. Присутствие такого неназванного лица можно усмотреть в семантике разных слов, ср., например, временное наречие сразу в пространственном значении: сразу за углом, сразу за иерковью, которое предполагает движущегося человека (ср. в других случаях скрытое присутствие наблюдателя, о чем много писалось).

Более сложный случай — лексема вести 7 'быть причиной': $K$ беде нeоnblmность ведет. Здесь неопытность (причина) трактуется как начальная точка того пути, конечной точкой которого оказывается беда (следствие). Более употребителен в этом значении приставочный глагол приводить, отчетливо сохраняющий идею движения. Таким образом, в данном случае мы имеем дело с деривацией на основе метафоры.

Если для глагола вести общей семантической основой является каузация движения, то для глагола валить такой общей семантической основой можно считать каузацию изменения положения объекта в пространстве, чтобы то, что стояло, стало лежать (один блок лексем) или перестало стоять на прежнем месте (другой блок); агенсом в этом случае является человек, группа людей или сопоставимые с человеком активные «деятели» - животные, стихии, болезни. Стоящие объекты действия (люди, предметы) в результате начинают лежать (этой семантикой объединяется бо́льшая часть лексем: валить деревья, валить противника на спину, валить медведя, чума валит людей и т.д.) или сдвигаются со своего исходного места (меньший блок лексем), причем часто в последних также присутствует идея опрокидывания и движения сверху вниз (валить ограждения, свалить книги со стола, валить вещчи в кучу). Если агенсом оказывается не человек или стихия, то 
действие метафорически уподобляется прототипическому физическому действию (ветер валит с ног - усталость валит с ног). Дальнейшая семантическая деривация обусловлена интерпретацией полученного положения (лежать $>$ быть больным, ср. слечь, лежать > быть убитым, стать мертвым, ср. полегли в бою). Метафорическое уподобление физическому действию представлено также в выражениях типа валить вину на другого. Иного объяснения требует глагол валить применительно к ситуации экзамена. Здесь, как кажется, имеет место не столько метафора провала (поражения) как результата «опрокидывания», сколько деривация (депрефиксация) от выражения провалиться на экзамене, откуда сначала каузатив провалить студента на экзамене, а затем и валить студентов на экзамене. Иначе говоря, здесь нет семантического развития от прототипического физического значения глагола валить, а есть конденсация словосочетания и дальнейшая словообразовательная деривация.

Оба рассмотренных случая (с глаголом вести и глаголом валить) показывают, что на фоне общей семантической основы многозначного слова лучше видны механизмы формирования новых, производных значений за счет изменения (сдвига) каких-то элементов прототипической семантики слова. Когда речь идет о каузативных глаголах, важно учитывать не только непосредственные компоненты значения (значения глагольного класса и лексическое наполнение актантов), но и более широкое семантическое поле, включающее характерные свойства и актантную структуру предикатов. В семантической структуре каузативных глаголов, которые в стандартном случае имеют двух действующих участников, субъекта и пациенса, участвуют не только актанты основного предиката, но и актанты этих актантов (т.е. существенно не только кто и что ведет кого-л. или что-л., но и что «делает» тот, кого ведут, или то, что ведут).

\section{4. Структура и иерархия лексем многозначного слова}

Структура и иерархия лексем многозначного слова определяются двумя факторами: общей логикой соотношения лексем (cp. понятие прототипических, или основных, лексем и их производных, вторичных, возникающих в результате семантической деривации разного типа) и узусом, т. е. употребительностью той или иной лексемы (независимо от отношений производности).

У акционального имени в соответствии с «логикой» на первом месте дается его акциональное значение, затем может идти персонифицированное значение деятеля, а после него вторичные предметные, специальные или переносные значения. Например, синопсис слова защита имеет следующую структуру: первый блок включает исходное акциональное значение $(1.1$ - защита слабых $)$ и непосредственно производное от него агентивное (персональное) значение (1.2- сторона защиты ); следующий блок (2.1-3) охватывает более узкие и специальные значения (самооборона, шахматное, футбольное); в третьем блоке (3.1-4) защита понимается как форма поведения (защита от нападок прессы, защита чести и достоинства, защита в суде и т. п.); четвертый блок (4.1-3) включает значения, трактующие 
защиту не как акциональное, а как стативное имя (защита от влаги и далее - объект, служащий защитой, приспособление для защиты); наконец, в качестве отдельного блока (5) приведено «специализированное» значение 'защита диссертации'.

Семантическая структура прилагательных обычно выстраивается в соответствии с носителем свойства (человек - часть тела человека - его действия, состояния, атрибуты, характерные события и ситуации), например для весельй: 1.1. постоянное свойство человека, 1.2. актуальное свойство (состояние) человека (им было весело), 1.3. часть тела человека, выражающая это состояние (лицо, глаза), затем объекты и ситуации, в которых человек является субъектом действия, состояния или восприятия, 1.4. разговор; 2.1. пир, 2.2. детская площадка; 3.1. спектакль, 3.2. пейзаж; 4. азарт. Подобную последовательность значений имеют и другие прилагательные, ср. бодрый: 1. человек, 2.1. настроение, дух, 2.2. голос, походка, 3. песня; вежливый: 1. ребенок, продавец, 2.1. тон, жест, 2.2. письмо, ответ. Однако в случае волевой последовательность обратная: сначала дается значение, относящееся к поведению человека (волевое усилие), затем - к самому человеку (волевой юноша), и за ним - к части тела (волевое лиц̧о), ср. также вредный: 1. привычка, 2. человек.

Очень четкая логическая схема выдержана в статье болезненный (относительное прилагательное), где выделены функции атрибута, относящиеся не столько к мотивирующему слову болезнь, сколько к его мотивирующему - глаголу болеть: 1.1. 'часто болеющий' (человек), 1.2. 'свидетельствующий о болезни' (румянец), 2.1. 'вызывающий боль' (укол), 2.2. перен. 'вызывающий страдание’ (расставание), 3. 'выражающий боль' (стоны), 4. перен. (по признаку аномальности) 'чрезмерный' (любопытство). Но иногда предпочтение отдается узусу. Например, у слова возвышенный на первом месте стоят «переносные» значения: возвышенные 1.1. чувства, 1.2. слова, речи, 1.3. душа, натура, а первичное пространственное значение помечено номером 2: возвышенная местность.

В глаголах, как правило, сначала дается акциональное значение, а потом стативные (состояния, свойства и т.п.), но в случае венчать сделано наоборот: 1.1. купол венчает здание, 1.2. диадема венчает голову, 2. сказку венчает пир, 3.1. 'сочетать браком', 3.2. 'возводить на престол', 4. 'увенчивать чемпиона'.

\section{5. Многозначность, семантическая деривация и словообразование. Внешняя и внутренняя деривация}

В «Лексической семантике» Ю. Д. Апресян проблеме соотношения словообразования и многозначности посвятил отдельную главу, где это соотношение сформулировано в общем виде: «Аналогия между словообразованием и многозначностью простирается настолько далеко, что к ней оказываются применимыми такие типично словообразовательные понятия, как регулярность - нерегулярность, продуктивность - непродуктивность и др.» [Апресян 1974: 189], — и рассмотрены под этим углом зрения виды регулярной многозначности существительных, глаголов и прилагательных. Продолжая эту линию сопоставления явлений многозначности 
и словообразования с учетом новейших представлений о лексической многозначности, необходимо обратить внимание на еще одно важнейшее свойство, объединяющее их.

В 1974 г. еще не было введено понятие лексе мы, т. е. слова в одном из его значений, обладающего всей полнотой грамматических, стилистических, акцентуационных и прочих признаков и являющегося в сущности основной единицей лексической системы языка (субъектом системных отношений). Действительно, системные отношения между лексическими единицами (синонимия, антонимия, аналогия и др.) связывают не целые слова, а конкретные лексемы. Однако в теории словообразования дело обстоит иначе: субъектами словообразовательных отношений принято считать именно слова ${ }^{4}$. Между тем очевидно, что и в словообразовании отношения производности (мотивированности) связывают не слова, а лексемы. Если от многозначного глагола водить мы имеем производное имя со значением лица водитель, то мотивирующим для него является не глагол в целом (водителем не называется тот, кто водит ребенка в школу), а только одна из его лексем ('управлять транспортным средством'), и точнее даже не эта лексема во всем объеме ее употреблений, а только некоторые ее «подлексемы», потому что, хотя водить можно и машину, и поезд, и корабль, водителем называется только управляющий автомобилем, автобусом или трамваем, но не управляющий поездом, вертолетом или судном.

Понятие семантической деривации, широко употребительное в отечественной семасиологии по крайней мере с 1960-х гг. [ср.: Шмелев 1964: 56], в последнем обзоре понятийного аппарата системной лексикографии [Апресян 2009: 486-552] не получило определения 5 . Обычно оно понимается динамически - как способ образования одного значения производного слова от другого, а совокупность разных значений слова иногда называется парадигмой его лексем [Падучева 2000; 2004]

4 Это объясняется прежде всего тем, что словообразование изучает не только семантическую сторону производности, но и формальную, а в формальном отношении производящее слово, как правило, «едино» во всех своих значениях.

5 Для понятия «дериват» дается словообразовательное и семантическое определение: «Дериват, или производное: а) слово, в составе которого вычленяются корень и аффикс(ы) и значение которого мотивировано значениями этих составляющих его частей (канонический случай, ср. дериваты глагола строить - слова строительство, строитель, строительный, постройка, строение и т. п.), а также б) любое другое слово, семантическое отношение которого к исходному слову совпадает или сходно с семантическим отношением между словами в случае канонической деривации. Ср. слово врач, семантическое отношение которого к исходному глаголу лечить точно такое же, как у канонических производных имен деятеля в парах строитель - cтроить, учитель - учить, изобретатель - изобретать». И далее: «Деривация - образование деривата (см.)» [Апресян 2009: 499].

${ }^{6}$ Ср.: «Семантическая деривация позволяет представить совокупность значений слова как единую структуру - как парадигму его лексем, такую же, как парадигма грамматических форм у слова заданной части речи или грамматического разряда. $<\ldots>$ Параметрами грамматической парадигмы являются грамматические категории (например, для парадигмы прилагательного это будут род, число, падеж, одушевленность). Для семантической парадигмы это параметры 
При этом во многих работах явление многозначности связывается с различным восприятием (особыми акцентами, специальным фокусированием) разных аспектов и компонентов исходной (прототипической) ситуации [Падучева 2004; Кустова 2004; Розина 2005; Зализняк 2006]. Этот «когнитивный» механизм действительно лежит в основе многих производных лексических значений, что убедительно показано в указанных выше работах. Он предполагает непосредственную производность одного значения многозначного слова от другого. Парадигма многозначности в этом случае предстает как внутренний механизм, определяющий отношения между лексемами многозначного слова.

Между тем во многих случаях значение лексемы многозначного слова не выводится из семантики других лексем, а «наводится» извне, т. е. возникает под влиянием других слов, находящихся в системной связи с данным словом (синонимов, антонимов, конверсивов, аналогов, дериватов и т.п.), и/или путем конденсации устойчивых выражений с данным словом. Упоминавшееся выше значение вести 9 'разг. выслеживать кого-л.' производно не от какой-то другой лексемы глагола вести, а от выражения вести слежку за кем-л. (ср. вести занятия по математи$\kappa е>$ вести математику), т. е. оно входит в «парадигму» лексем глагола со стороны (при этом вести слежку представляет стандартный тип: вести работу, исследования и т.д.). Дериваты разных лексем многозначного слова могут не иметь между собой прямой семантической связи, а соотноситься опосредованно, через семантику производящего слова. Например, возвышенность как природный объект является дериватом прилагательного возвышенный в физическом значении, а возвышенность как душевный настрой - дериват другой лексемы того же прилагательного; эти две лексемы имени возвышенность не связаны друг с другом непосредственными деривационными отношениями (т. е. семантически не производны друг от друга) и по существу являются внутренними омонимами.

В семантическом спектре глагола зайти деривационными отношениями так или иначе связаны все лексемы, кроме зайти 8 с начинательным значением (зашел cnop); последняя не может считаться дериватом исходного (пространственного) значения, а является по существу омонимичным ему. Значение валить 7 (валить студентов на экзамене) невозможно вывести из семантики какой-либо другой лексемы глагола валить, оно является продуктом серии вполне стандартных изменений: провалиться на экзамене (ср. провалиться сквозь землю от стыда, потерпеть провал) > провалить студента на экзамене > валить студентов на экзамене. Валить 6 (валить вину) скорее является продуктом обратной деривации от глагола сваливать (вину на другого), а лексема варить 3 (У больного плохо варит желудок) вторична по отношению к таким выражениям, как переваривать пищу, несварение желудка. Лексему влияние 2 (использовать его влияние) можно понимать как обратный дериват от влиятельный (в значении 'влиятельность', т. е. как имя

лексического значения: категория, тематический класс, диатеза и таксономический класс участника» [Падучева 2004: 149-150]. 
свойства, ср. бирюза < бирюзовый: бирюза морской воды, т. е. 'бирюзовость', выгода в значении 'выгодность': выгодное положение > выгода его положения).

Лексемы диплом 2.1 (тема диплома) и 2.2 (У него через месяи диплом) не являются дериватами лексемы диплом 1 (университетский диплом), а представляют собой результат конденсации словосочетаний дипломная работа и защита диплома соответственно (ср. аналогично присяга в значении 'принятие присяги': У него через месяц присяга). Полька как название танца производно не от названия национальности, а является конденсацией выражения польский танеи (пляcка), то же можно сказать о лексеме венгерка 'венгерский танец' (ср. сплясать русскую, лезгинка); иначе говоря, лексемы с семантикой танца и со значением национальности по существу омонимичны. То же можно сказать о лексемах дирекциия 1 'руководство' и дирекция 2. (заседание дирекции) и многих других подобных случаях ${ }^{7}$.

Отношения семантической деривации не замыкаются в границах одного слова, они продолжаются в семантически и формально (словообразовательно) связанных с ним лексических единицах, и типология этих связей нуждается в изучении. Имя защиттник в своем семантическом спектре (системе лексем) повторяет структуру многозначности производящего глагола защищзать в той зоне значений, которая касается акциональной семантики; однако стативные значения глагола (защзищать oт солнияа, om ветра) не получают продолжения в структуре производного имени деятеля (*защитник от солнца), в отличие от имени защита, которое не только включает дериваты от стативных лексем, но и продолжает эту линию деривации в предметной сфере (поставить защзиту на руль автомобиля).

В деривационном гнезде бежать / бегать (бег, бегльй, беглеи, бегом, бегство, бегун, беженеи) лексемы с семантикой удаления (бежать / бегать откуда, от чего-л.) обособлены от других: эта семантика вообще не характерна для бег, бегом и бегун, производных от глагольных лексем с семантикой быстрого перемещения; в остальных дериватах семантика удаления либо формирует особый блок лексем (как в бегать, бежать, бегльй), либо вообще оказывается единственной (как в бегство, беженец). В структуре многозначности прилагательного военный есть лексемы, семантически производные от имени война (военная угроза), от имени армия (военная служба), от субстантивированного военный (военная выправка, военный городок), соответственно, в одних контекстах прилагательное соотносится с антонимом мирныцй, в других - с гражданский, в третьих - со штатский.

Все такого рода явления семантических отношений, выходящие за рамки одного слова, безусловно, заслуживают дальнейшего изучения, систематизации и типологического осмысления.

${ }^{7}$ Мне уже приходилось писать о «квазиомонимичности» лексем многозначных слов [см.: Толстая 2006; Толстая 2008: 21-31]. 


\section{Литература}

Апресян Ю.Д. Лексическая семантика. Синонимические средства языка. М. : Наука, 1974. 367 с.

Апресян Ю.Д. Акциональность и стативность как сокровенные смыслы (охота на оказывать) // Сокровенные смыслы. Слово. Текст. Культура : сб. ст. в честь Н. Д. Арутюновой / отв. ред. Ю. Д. Апресян. М. : Языки славянской культуры, 2004. С. 13-33.

Апресян Ю.Д. Исследования по семантике и лексикографии. Т. 1 : Парадигматика. М. : Языки славянских культур, 2009. 567 с.

АС - Апресян Ю.Д., Апресян В.Ю., Бабаева Е. Э., Богуславская О. Ю., Галактионова И. В., Гловинская М.Я., Иомдин Б. Л., Крылова Т. В., Левонтина И. Б., Лопухина А.А., Птенцова А.В., Санников А.В., Урысон Е.В. Активный словарь русского языка / отв. ред. акад. Ю. Д. Апресян. Т. 1 : А-Б . 408 с. ; Т. 2 : В-Г. 736 с. М. : Языки славянских культур, 2014 ; Т. 3 : Д-3. М. ; СПб. : Нестор-История, 2017. $768 \mathrm{c}$.

Зализняк Анна А. Многозначность в языке и способы ее представления. М. : Языки славянских культур, 2006. 671 с.

Кустова Г.И. Типы производных значений и механизмы языкового расширения. М. : Языки славянских культур, 2004. 472 с.

НОСС - Апресян Ю.Д., Апресян В. Ю., Бабаева Е. Э., Богуславская О.Ю., Галактионова И.В., Гловинская М.Я., Иомдин Б. Л., Крылова Т. В., Левонтина И.Б., Птенцова А. В., Санников А. В., Урысон Е. В. Новый объяснительный словарь синонимов русского языка / под общ. рук. акад. Ю. Д. Апресяна. 2-е изд., испр. и доп. М. ; Вена : Языки славянской культуры, 2004. 1417 с.

Падучева E. B. О семантической деривации: слово как парадигма лексем // Русский язык сегодня. Вып. 1 / отв. ред. Л.П. Крысин. М. : Азбуковник, 2000. С. 395417.

Падучева Е.В. Динамические модели в семантике лексики. М. : Языки славянских культур, 2004. 1055 с.

Розина Р.И. Семантическое развитие слова в русском литературном языке и современном сленге. Глагол. М. : Азбуковник, 2005. 301 с.

Толстая С. М. [Рец. на кн.]: Розина Р.И. Семантическое развитие слова в русском литературном языке и сленге // Известия РАН. Серия литературы и языка. 2006. Т. 65. № 4. С. 66-69.

Толстая С.М. Пространство слова. Лексическая семантика в общеславянской перспективе. М. : Индрик, 2008. 537 с.

Толстая С.М. Тип субъекта и многозначность глагола // У простору лингвистичке славистике : зб. радова поводом 65 година живота академика Предрага Пипера / приред. Љ. Поповић, Д. Војводић, М. Номаћ. Београд : Филолошки факултет, 2015. С. 705-726.

Шмелев Д. Н. Очерки по семасиологии русского языка. М. : Просвещение, 1964. $243 \mathrm{c}$. 


\section{S. M. Tolstaya \\ Institute of Slavistics of the Russian Academy of Sciences \\ (Russia, Moscow) \\ smtolstaya@yandex.ru}

\section{MECHANISMS OF LEXICAL POLYSEMY: MARGINAL NOTES TO THE ACTIVE DICTIONARY}

The Active dictionary of the Russian language, edited by Yu.D. Apresyan, introduces a new approach to lexical polysemy, its system, typology, and its mechanism. Different word classes have different degrees and different types of polysemy. In general, polysemy is less typical for subject words than for predicate ones and especially verbs, due to the complexity of the verb actant structure and the dependence of verb semantics on the lexical classes of its actants. Lexical polysemy is based on the following system mechanisms: metonymy and metaphor (typical for both subject words and predicates), the fundamental classification of predicates and predicate names, the system of their semantic (functional) actants (subject, object, counterpart, patient, tool, means, goal, locus, time, method, etc.), and the "taxonomic" classification of vocabulary (both subject and predicate). These statements are illustrated by the interpretation of the verbs vesti 'to lead,' valyat' 'to bring down, to throw down,' etc. The main difference between the identified meanings (lexemes) of the polysemous verb vesti lies in the lexical classes to which its object or patient (person or group of persons, vehicle, occupation or activity, finger, eye, etc.) belongs. The common semantic foundation for the former different meanings proves to be "the causation of object movement" with a formal indicator that the objects (patients) of the action vesti usually combine with the predicate idti 'to go' (mashina idet 'the car is moving,' urok idet 'the class is underway,' issledovaniya idut 'the research is underway,' etc.). For the verb valyat', the common semantic foundation can be considered "the causation of changing the position of an object in space." The lexeme of a polysemous word is not necessarily a semantic derivative of the other lexeme of the same word - it may appear "outside," i.e. influenced by the correlative words (synonyms, antonyms, conversives, analogues, derivatives, etc.) and/or by condensation of fixed expressions with this word.

Key words: lexical polysemy, lexical classes, subject vocabulary, predicate vocabulary, semantics, semantic derivation, Russian language.

\section{References}

Apresyan Yu.D. Leksicheskaya semantika. Sinonimicheskie sredstva yazyka [Lexical Semantics. Synonymous Means of Language]. Moscow, Nauka Publ., 1974, 367 p.

Apresyan Yu.D. [Actionality and Stativity as Hidden Meanings (Hunting for render)]. Sokrovennye smysly. Slovo. Tekst. Kul'tura: sb. st. v chest' N.D. Arutyunovoi [Hidden Meanings. Word. Text. Culture: A Collection of Articles in Honor of N.D. Arutyunova]. 
Yu.D. Apresyan (Ed.). Moscow, Yazyki slavyanskoi kul'tury Publ., 2004, pp. 13-33. (In Russ.)

Apresyan Yu.D. Issledovaniya po semantike i leksikografii. T. 1: Paradigmati$k a$ [Studies on Semantics and Lexicography. Vol. 1. Paradigmatics]. Moscow, Yazyki slavyanskikh kul'tur Publ., 2009, 567 p.

Apresyan Yu.D., Apresyan V.Yu., Babaeva E.E., Boguslavskaya O.Yu., Galaktionova I.V., Glovinskaya M.Ya., Iomdin B.L., Krylova T. V., Levontina I.B., Lopukhina A. A., Ptentsova A.V., Sannikov A.V., Uryson E. V. Aktivnyi slovar' russkogo yazyka [Active Dictionary of the Russian Language] (Vols. 1-3). Yu.D. Apresyan (Ed.). Moscow, St Petersburg, Yazyki slavyanskikh kul'tur Publ., 2014-2017.

Apresyan Yu.D., Apresyan V.Yu., Babaeva E.E., Boguslavskaya O.Yu., Galaktionova I. V., Glovinskaya M.Ya., Iomdin B. L., Krylova T. V., Levontina I. B., Ptentsova A. V., Sannikov A. V., Uryson E. V. Novyi ob"yasnitel'nyi slovar' sinonimov russkogo yazyka [New Explanatory Dictionary of Russian Synonyms] ( $2^{\text {nd }}$ Ed.). Yu.D. Apresyan (Ed.). Moscow, Vienna, Yazyki slavyanskoi kul'tury Publ., 2004, 1417 p.

Kustova G.I. Tipy proizvodnykh znachenii i mekhanizmy yazykovogo rasshireniya [Types of Derivative Meanings and Mechanisms of Language Extension]. Moscow, Yazyki slavyanskikh kul'tur Publ., 2004, 472 p.

Paducheva E. V. [On the Semantic Derivation: A Word as a Paradigm of Lexemes]. Russkii yazyk segodnya: sb. st. pamyati D. N. Shmeleva [The Russian Language Today: A Collection of Papers in Memory of D. N. Shmelev]. L. P. Krysin (Ed.). Moscow, Abukovnik Publ., 2000, pp. 395-417. (In Russ.)

Paducheva E. V. Dinamicheskie modeli v semantike leksiki [Dynamic Models of Lexical Semantics]. Moscow, Yazyki slavyanskikh kul'tur Publ., 2004, 1055 p.

Rozina R. I. Semanticheskoe razvitie slova v russkom literaturnom yazyke i sovremennom slenge. Glagol [The Semantic Development of the Word in the Standard Russian Language and in Contemporary Slang: The Verb]. Moscow, Azbukovnik Publ., 2005, 301 p.

Shmelev D. N. Ocherki po semasiologii russkogo yazyka [Essays on Semasiology of the Russian Language]. Moscow, Prosveshchenie Publ., 1964, 243 p.

Tolstaya S. M. [Book Review: Rozina R.I. The Semantic Development of the Word in the Standard Russian Language and in Contemporary Slang]. Izvestiya RAN. Seriya literatury i yazyka, 2006, Vol. 65, No. 4, pp. 66-69. (In Russ.)

Tolstaya S. M. Prostranstvo slova. Leksicheskaya semantika v obshcheslavyanskoi perspective [Extent of a Word. Lexical Semantics in the Common Slavic Perspective]. Moscow, Indrik Publ., 2008, 537 p.

Tolstaya S.M. [The Subject Type and the Polysemy of a Verb]. U prostoru lingvistichke slavistike: zb. radova povodom 65 godina zhivota akademika Predraga Pipera [In the Linguistic Space of Slavistics: A Collection of Articles in Honor of the $65^{\text {th }}$ Anniversary of Predrag Piper]. L. Popovich, D. Vojvodich, M. Nomach (Eds.). Belgrade, Philological Faculty Publ., 2015, p. 705-726 (In Russ.)

Zaliznyak Anna A. Mnogoznachnost'v yazyke i sposoby ee predstavleniya [Polysemy in Language and the Methods of its Presentation]. Moscow, Yazyki slavyanskikh kul'tur Publ., 2006, 671 p. 